\title{
sciendo
}

\section{Academic leadership: agility in the digital revolution}

\author{
Alina Mihaela DIMA \\ The Bucharest University of Economic Studies, Bucharest Romania \\ e-mail: address alina.dima@ase.ro \\ Sebastien POINT \\ EM Strasbourg Business School, Université de Strasbourg, France \\ Maria Alexandra MAASSEN \\ The Bucharest University of Economic Studies, Bucharest Romania \\ e-mail address maria_nichifor@hotmail.com

\section{Adela JANSEN} \\ The Bucharest University of Economic Studies, Bucharest Romania \\ e-mail address jansen.adela@yahoo.com
}

\begin{abstract}
The COVID-19 pandemic has brought tremendous challenges for the educational field, especially in terms of leadership strategies to be taken on a short notice in order to ensure both health security of the personnel and learners, but also adapt to an online teaching environment and other challenges. While several higher education institutions had partially or completely adapted to an online educational model, the COVID-19 period offered new challenges in terms of internationalization, investment in technology and financing, but also in terms of implementing new educational models, fully online or hybrid models. Based on a sample of 23 Universities from the European Union, the current research aimed to propose new directions of the academic leadership strategies and focus points during the COVID-19 pandemic, as well as expected trends after the end of the pandemic.

Based on the study of the academic leadership strategies and models in the European Union, this paper offers an additional practical overview to existing studies in the field, as it inquires the implemented university leadership strategies in order to adapt and overcome the current pandemic crisis, as well as ensuring the continuity of activities and development of higher educational institutions.
\end{abstract}

Keywords: Academic leadership, higher education, online learning, crisis, educational model.

\section{Introduction}

Higher education institutions are complex organizations, very sensitive to external environmental forces, which may influence organizational workflow, mission and goals of the academic institutions (Pucciarelli \& Kaplan, 2016). Leaders and leadership are topics relevant both for academia and practitioners (Balan et al., 2019). According to Saroyan et al. (2011) academic leadership is oriented towards student learning improvement implemented by any administrative leader, faculty member or a professional support individual. Thus, academic leadership is focused on bringing a better quality of learning for the students. Consequently, institutional reputation and standing are influenced by the social construction and perceptions of their response to external events (Blumenstyk, 2014, Gmelch et al., 2017, Weick et al., 2005, Fink, 2002, Kruse et al., 2020). Crisis leadership tailors' responses to complex audiences based on internal and external stakeholders (Stephens, Malone \& Bailey, 2005). Methods of transmitting the message to the right audience, at the right time are leadership instruments that include both the situation and the context. 
In the same vein, the COVID-19 pandemic has emphasized the need for higher education institutions to adapt their leadership and educational models to new ways of acting in order to preserve the continuity and quality of education, as well as healthcare safety of their staff and learners (IAU, 2020b). The pandemic situation has been understood as an opportunity for change and innovation, for new models and educational pattern (Yan, 2020). Based on the new social restrictions imposed by authorities, the leadership of higher education institutions imposed new strategic educational models, allowing more innovation and flexibility within the organizations and its processes. For example, in the United States higher education institutions (HEIs) promoted a type of servant (service) leadership based on empowerment, involvement and collaboration, where leaders put the interests of others above of their own (Fernandez and Shaw, 2020). Factors, such as funding, investment orientation, outgoing or incoming student mobility, moving to a full online education, at lease for a few months were issues, that had to be implemented within a couple of weeks, if not days (IAU, 2020a, IAU, 2020b).

Internationalization of the universities was one of the most affected fields, two-thirds of institutions reporting a high impact of their outgoing student mobility, but only about half of them reported an impact on their incoming student mobility (IAU, 2020a). This was mostly due to border restrictions, quarantines after entering or exiting certain countries, rules of social distancing and other such issues imposed for the citizens health safety. Furthermore, international research and cooperation through international conferences, that had to move completely online or had to postpone these international activities for an undetermined period or mobility if international guest researchers were reduced or cancelled. This has encouraged mostly the trend of internationalization at home given existing technology and on-line branding of these activities (Brandenburg, 2020).

The pandemic period increased the trend of the technological investment, through the acquisition of new software, modules, videos, online platforms, licenses and various databases (Brookings, 2020). The HolonIQ website ${ }^{1}$ mentions that the first half of 2020 was the secondlargest semester for global ed-tech investment, respectively $\$ 4.5$ billion, three times greater than the average 6-months of VC investment during the prior decade. Much of this investment was concentrated on higher education and its intersection with the workforce. According to O'Malley (2020): health and risk management (87\%), followed by financial challenges (74\%), maintaining the quality of programs (70\%), student retention success (67\%) and student enrolment (58\%) could be considered the most significant aspects of financial dimension in the academic leadership during the COVID-19 pandemic. Thus, the current scientific literature mostly presents general data regarding the measures imposed by governments or locally by ministries to University leadership personnel, however few studies (IAUP, 2020) have inquired specific implemented strategies of Universities' leadership during the COVID-19 pandemic and clear directions after the pandemic ends. In terms of academic leadership according to the scientific literature the main focus remains ensuring the quality of the students learning.

The present study intends to offer an overview of such specific strategies implemented by a panel of Universities from Romania and from other European Union countries.

\section{Literature review}

As the COVID-19 pandemic emerged as a global crisis imposing new measurements of security in terms of healthcare, managing global economic systems and finding new competitive strategies in terms of business especially, the Universities also had to adjust to innovative ways of coping with

${ }^{1}$ https://www.holoniq.com/notes/4.5b-global-edtech-venture-capital-for-q1-2020/. 
the challenge based on digitalization and new leadership strategies. Primarily, it accelerated the digital revolution (Kaplan \& Haenlein, 2016) by fostering the transition from on-campus classes to digital teaching systems. Furthermore, regulations and government decisions, as well as local organizational decisions of several organizations, such as border closures, decrease of aviation capacity, compulsory quarantine when travelling to a country, restrictions on mass gatherings, and distancing restrictions, imposed challenges and change management measures in order to ensure the health safety of the higher education institution members and simultaneously a smooth flow of the teaching activity (Brammer and Clark, 2020).

While educational facilities had to adapt in a matter of months or even weeks to a partial or a complete online educational system, the Universities also had to adjust the four pillars of organizational effectiveness in higher education institutions, namely the academic domain, the moral domain, the adaptation and the external interaction domain and extracurricular activities domain, as shown in Table 1 (Sa and Serpa, 2020).

Table 1. The four pillars of higher education institutions (HEIs)

\begin{tabular}{|l|l|}
\hline Academic domain & $\begin{array}{l}\text { Supports students' educational development within the University, } \\
\text { professional satisfaction of the staff and ensuring the necessary resources }\end{array}$ \\
\hline Moral domain & $\begin{array}{l}\text { Focuses on the academic satisfaction of students and the professional } \\
\text { satisfaction of the HEI staff and the robustness of the internal institutional } \\
\text { processes }\end{array}$ \\
\hline $\begin{array}{l}\text { Adaptation and external interaction } \\
\text { domain }\end{array}$ & Supports the career development of students \\
\hline Extracurricular activities domain & Supports the personal development of students \\
\hline
\end{tabular}

Although most studies refer to the digitalization of classes in the case of higher educational institutions, the change management of social and organizational elements of these institutions is often neglected. Higher education institutions had to adapt to offering online classes in order to ensure the continuity of their learners' educational process and their educational and noneducational staff activity. However, after these new challenges emerged in terms of social and organizational elements, such as: the issue of attracting new students in the following years, retaining students, retain high academic standards and quality assurance procedures without compromising them (Gamage et al., 2020). Furthermore, Fernandez and Shaw (2020) mention another challenge, respectively the need for university leadership to communicate clearly and frequently to all stakeholders through a wide variety of communication channels in order to ensure a good foundation for online system during the COVID-19 pandemic.

One of the main issues of the pandemic imposed online educational systems is the restricted or lacking access to Internet or technological devices in many regions of the world, restricting educational access to many learners. For example, at the beginning of the COVID-19 crisis in the United States, we have evidence that $15 \%$ of US households with children did not have a highspeed Internet connection at home (Harris, 2020).

Other challenging issues higher education institutions had to face due to restricted access within certain countries, attracting international students' enrolment, faculty training for online, hybrid, or remote education, mental health support for students, purchasing new or improving existing technology, including HEI educational platforms, purchasing access for staff for license and other, which were needed for online, hybrid, or remote education (IAUP, 2020). Such 
additional challenges also brought higher amounts of workload and stress for many of its members, that combined with organizational changes placed the HEIs leadership in not well-known areas and in the position to reconsider strategies for student retention, recovery methods for the negative financial effects, and identify moral and creative ways to continue marketing for enrolment (Singh and Haynes, 2020).

Consequently, leadership methods also had to adapt in terms of a more authentic leadership, emphasizing mostly self-awareness of leader's own strengths and weaknesses, as well as their impact from other members perspective and the balancing process, implying the thorough analysis of all elements before taking a decision, especially in the context of online communication and action throughout the activity during the COVID-19 pandemic period (Tran, 2019).

In terms of the types of educational leadership that already exist, Figure 1 is illustrative. In the model of Lynch these four types of educational leadership offer the main current trends, respectively:

- the transactional leadership, as the typical model of a transactional character of the relationship between employer and employee, which is paid;

- the service leadership, where the leader is supporting their employees through guidance, empowerment for several tasks and trust;

- emotional leadership, where leaders strive to find strategies to stimulate motivation of employees;

- transformational leadership, considered as the most suitable one for education, as it takes from all other leadership models the best and combines them for achievements in terms of personnel, goal of the organization and its stakeholders (Lynch, 2016). Furthermore, as mentioned by Goleman (1997), emotional intelligence became part of the transformative model that influenced HR leadership understanding (Astin \& Astin, 2000), focusing also on sector challenges in a global and customer centric world.

Referring to higher education leadership, Bass \& Avolio (1993) state the preference for a combination of transactional and transformational model added in a situational context. Due to complex environmental changes, transformational competencies and traits have become more important since the year 2000 (Kennedy, 1994; Tourish, 2008), emphasizing the importance of influence and sharing, coming after an era of "transactional-transformational" model in the 1970s when judgement, experimentation, competences were valued (Burns, 1978; Bass, 1997). Another author mentions leadership nominations should be based more on skills than on seniority (Altbach, 2011).

There is also another new concept regarding leadership, namely the sustainability leadership model. Based on the situational theory, Visser and Courtice (2011) state that the sustainability leadership model focuses on the internal and external context, at the individual level of know-how, experience, skills and competencies related to actions. In a world that is radically changing in terms of technological development, self-learning could be an answer in higher education for personal development, as a role model for students and as innovation practical method, searching, experimenting, piloting in the same time on content, tools and partnerships.

Being related to the practical skills and competencies of persons or of the organization in order "to guide followers, such as employees and team members and to take actions" leading to organizational outcomes (Filho, 2020), sustainable leadership can be embraced by anyone in its value chain. It can be analyzed through the angle of long-term value co-creation of benefits for involved actors in a more and more complex environment. 


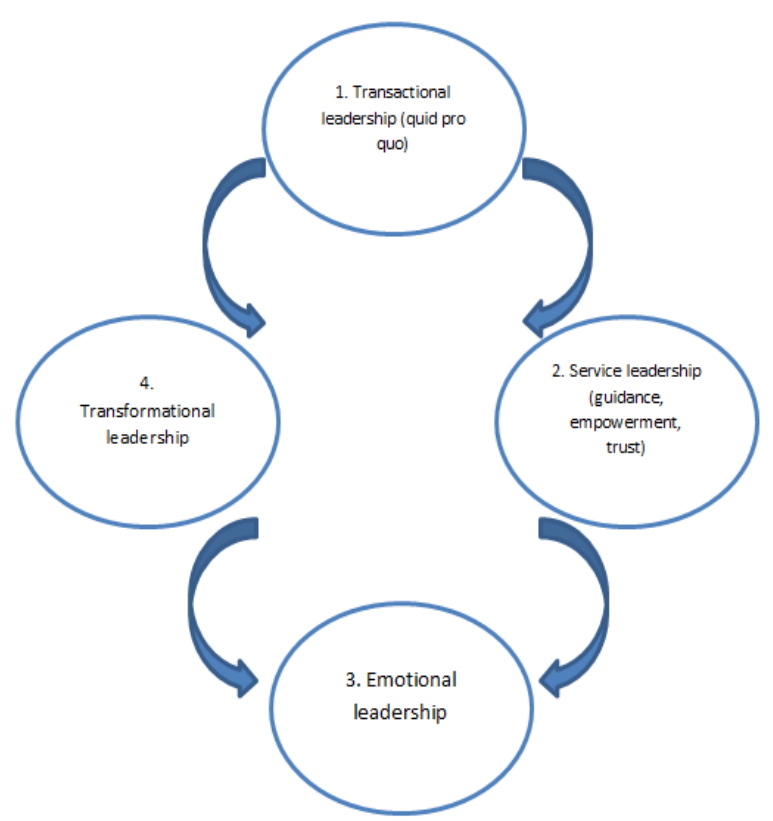

PICBE |

Figure 1. Types of educational leadership

Source: Lynch, 2016.

The COVID-19 pandemic has opened the opportunity of a new type of classification of educational leadership, especially in terms of higher educational facilities, which were forced to impose new educational models. While there are studies briefly describing some methods of University leadership dealing with challenges of the COVID-19 pandemic there were no studies with new types of classifications of educational models so far. Based on the adaptation from this model and the findings of the study we present in the practical part of the study a new category of classification for University leadership styles, namely digital visionary, transitional visionary and transformational visionary, which will be explained in the Findings section of the paper.

\section{Methodology}

The main objectives of the present research are:

1. Estimating the changes of the COVID-19 crisis on the academic leadership based on interaction with different categories of stakeholders;

2. Identifying some main priorities for the investment strategy according to the digitalization trends;

3. Determining the focus of strategic orientation and performance evaluation determinants;

4. Evaluating the institutional brand in the context of the new rankings and classifications;

5. Setting up new types of educational models according to the strategic priorities, focus and dimensions of the selected Universities for the research.

As a research instrument, we used online questionnaire sent to various universities from Romania and from abroad. We received 23 valid answers, respectively: 13 from Romania, 1 from France, 1 from Italy, 2 from USA, 2 from Austria, 1 from Germany and 1 from Slovakia.

The type of questions we used is Likert scale from 1 to 5 and focusing on the main topics regarding the changes in academic leadership during and after the COVID-19 period. The practical research focused on expected trends during and after the pandemic as mentioned by the 
participating institutions to the study. While the first part of the study inquired how the pandemic changed the leadership, the second part of the study inquired the focus of the institutions towards adapting their educational models. The structure of the sample: $25 \%$ vice-deans, $20.8 \%$ deans, $4.1 \%$ chair of a department, $4.1 \%$ vice-rector, $4.1 \%$ rector; the rest of the respondents were in one of the categories: member in the department council, director of the center, teaching and research staff, deputy head. We performed an analysis based on the obtained answer by using Stata and we also performed an adjusted Wald test to test whether the null hypothesis can be rejected or not.

\section{Findings}

The first issue related to our research referred to how the pandemic changed the leadership in the academic institutions in terms of creating a stronger interaction with the academic community (staff, students, administrative personnel) based on a Likert scale from 1 to 5 . The mean is 2.54 and we obtained a linearized standard error of 0.208 .

The results show that the pandemic changed the leadership in the institution in terms of creating a stronger interaction with the academic community on average. This can be because the need for a closer cooperation for tasks during the COVID-19 pandemic emerged and although globally most academic programs developed online, the academic communities needed closer interaction in order to ensure successfully the performing of the current tasks. $50 \%$ of the respondents marked answer of 1, implying that it is very accurate, that the academic community evolved towards a very strong interaction.

In terms of the areas the academic leaders considered best prepared for managing the crisis effects on the university/organization, half of the respondents mentioned the restrictions of activities of some departments (libraries), while almost $21 \%$ mentioned the extension of activities of some departments. We performed an adjusted Wald test and we found values of (Prob $>F$ ) of above 0.05 for all answers, implying we cannot reject the null hypothesis in this case.

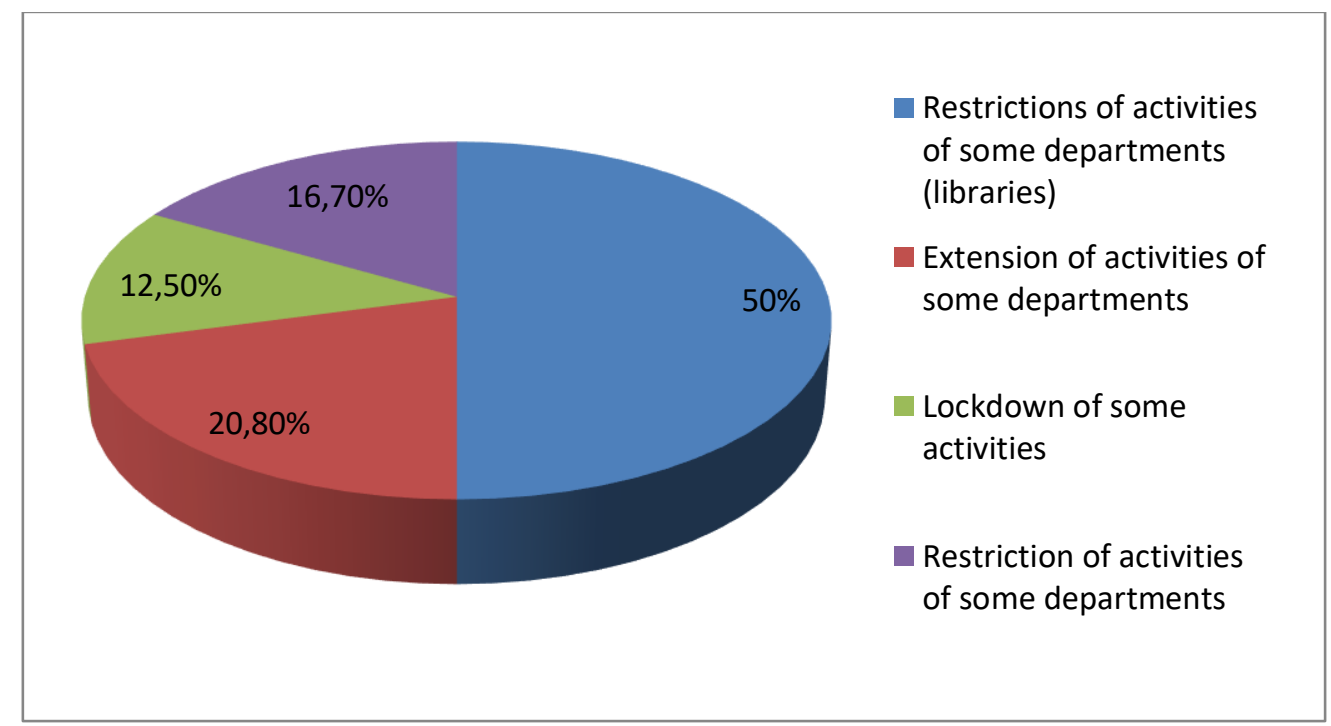

Figure 2. University area/dimensions that leaders considered mostly able to cope in the pandemic

Source: Authors' own research. 
Table 2. University area/dimensions that leaders considered mostly able to cope in the pandemic

\begin{tabular}{|l|c|c|c|}
\hline & Percentage & $\begin{array}{c}\text { Linearized } \\
\text { Standard Error }\end{array}$ & Adjusted Wald test \\
\hline $\begin{array}{l}\text { Restrictions of activities of some } \\
\text { departments }\end{array}$ & 0.5 & 0.11 & 0.1135 \\
\hline $\begin{array}{l}\text { Extension of activities of some } \\
\text { departments }\end{array}$ & 0.2 & 0.099 & 0.7 \\
\hline $\begin{array}{l}\text { Creation of new facilities or } \\
\text { instruments }\end{array}$ & 0.125 & 0.058 & 0.12 \\
\hline Lockdown of some activities & 0.166 & 0.105 & 0.48 \\
\hline
\end{tabular}

Regarding the new educational model, that will be implemented after the pandemic most participants $(62.5 \%)$ mentioned they would continue with a full online model, while $33.4 \%$ only mentioned going back to the traditional model.

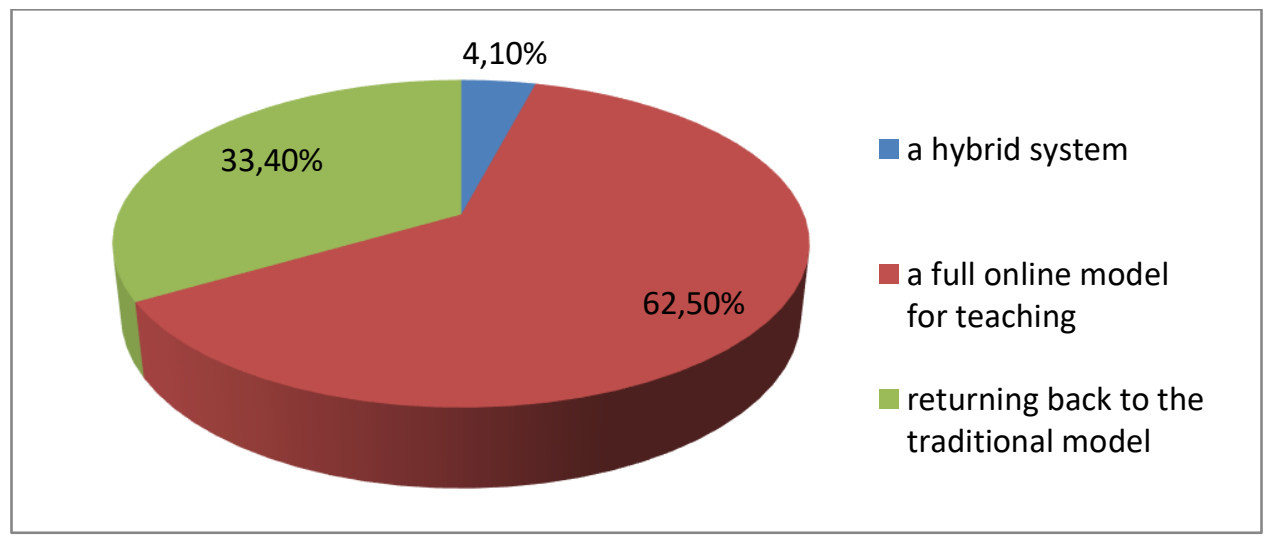

Figure 3. The perception of the new educational model after the pandemic

Source: Authors' own research.

This interesting result should be analyzed in further studies, corroborated with business environment ongoing surveys related to employers and employees' willingness to their collaborative way of working, whether it related to the workplace and way of work. According to Hays (2021) and Gartner (2020) about $80 \%$ of the work is desired to be done remotely for 3 to 5 days a week, so more than $60 \%$. Since the beginning of the pandemic, all companies are adjusting their work environment, work collaboration, impacting the organizational culture at individual and team levels, so employees-students too.

As online work seems to be totally of partially a clear trend, engagement and quality of work become an important subject in the long run in HE. Regarding virtual delivery of classes in $\mathrm{HE}$, there are advocates sustaining that bring more quality in problem solving and thinking skills (Politis and Politis, 2016) or enhanced communication according to Alavi and Galluope (2003), which disagrees with Sohn and Romal (2015) findings related to better students' performance in offline classes.

This liaison may be relevant as it could influence the students' behavior on medium-long term, as most of them are working during their studies, but also the existing employees willing to complete their education, which could represent a recruitment pool for universities. According with Crawford, Maccalman, \& Jackson, 2011; Felstead \& Henseke, 2017) underlined the benefits of remote work in personal commitment and job satisfaction which come although with the inability 
to switch-off. Also, according to Kniffin et al. (2020), many employees feel that working conditions have been deteriorated in COVID-19 pandemic due to burnout symptoms, feeling less motivated. According with Walker et al. (2020) prior experiences or during lockdown in online delivery have a positive impact on academics related to online work, as well as the ones that are more committed to their work, that proved mental resilience and energy. Last but not least, as defined by Schaufeli, Salanova, González-Romá, \& Bakker (2002, p. 74), work engagement is "a positive, fulfilling, work-related state of mind that is characterized by vigor, dedication, and absorption", where are

PICBE | combined the mental resilience and energy, pride and enthusiasm, dedication to their work - all crucial factor for productivity and performance, attention to innovation and personal well-being, as stated by Bakker too (2008).

Furthermore, the HEI's leadership competencies should be furthermore analyzed, as a new way of teaching and staff management implies new abilities and competencies for teachers. HEI's leaders should be aware of and be involved in facilitating staff development (i.e. teachers, administrative, support employees).

Table 3. The perception related to the New educational models after the pandemic

\begin{tabular}{|l|c|c|c|}
\hline $\begin{array}{c}\text { New educational models after } \\
\text { the pandemic }\end{array}$ & Percentage & $\begin{array}{c}\text { Linearized Standard } \\
\text { error }\end{array}$ & Adjusted Wald test \\
\hline A full online model & 0.041 & 0.026 & 0.044 \\
\hline A hybrid system & 0.625 & 0.040 & 0.07 \\
\hline $\begin{array}{l}\text { Returning back to the traditional } \\
\text { model }\end{array}$ & 0.2916 & 0.053 & 0.49 \\
\hline
\end{tabular}

Source: Authors' own research.

In terms of the main focus of the University/academic model for the near future (6 months) this would be mainly oriented towards focusing on business partnerships and training modules/postgraduates' studies in the case of most participating institutions, as shown in Table 3.

In the case of the three elements of the model we cannot reject the null hypothesis, namely in the case of orientation towards student campaigns, focus on marketing strategies, focus on study program design. The respondents also referred to the main investment strategy orientation and most participants referred to professional trainings and human resources and digitalization as the main strategies, namely 0.25 in the case of the first orientation and 0.55 in the case of the second one.

Table 4. Main dimensions of the new university/academic model

\begin{tabular}{|l|c|c|c|}
\hline & Proportion & $\begin{array}{c}\text { Linearized Std. } \\
\text { Error }\end{array}$ & $\begin{array}{c}\text { Adjusted Wald } \\
\text { test }\end{array}$ \\
\hline Oriented towards student campaigns & 0.2 & 0.04 & 0.33 \\
\hline $\begin{array}{l}\text { Focus on business partnerships and } \\
\text { training modules/postgraduate studies }\end{array}$ & 0.1 & 0.02 & 0.006 \\
\hline Focus on marketing strategies & 0.45 & 0.067 & 0.06 \\
\hline Focus on study program design & 0.25 & 0.045 & 1 \\
\hline
\end{tabular}

Regarding the areas of development, the universities would develop to more effectively lead in this current crisis most respondents mentioned the teaching and learning area (45\%).

Further considerations related to findings, with focus on online, as a major trend for future HEI new business models. The universities, as learning organizations, they are complex and 
adaptive systems (Bratianu et al., 2020) that should adopt strategies and instruments to respond better to any changes of business and social environment.

\section{Conclusion and study limitation for further research}

The present article presents an overview related to university strategies to adapt and overcome pandemic crisis. The leaders of the universities as part of the sample considered that adaptation to the new context require changes or restriction of some past activities in compensation with new opportunities in terms of digitalization. Related to the future education trends and programs design, the majority of respondents consider the online teaching should be further corroborated with the ongoing working models' trends found in business environment.

Therefore, the HEI's existing leadership should evolve, new digital and transformational leadership styles may prevail while keeping traditional traits too, to be able to keep the pace with new teaching methodologies, strategy adaptation, teams' management. This is captured in the findings related to near future priorities identified in present study, where business partnerships and training modules/post graduate studies are most significant, requiring further attention to their evolution too, to maximize the success.

According with our research, there is an expectation that blended or online teaching and assessment will be significant also in the future, as already the pandemic determined new skills and competencies (Greenberg \& Hibbert, 2020),

So further studies should investigate what would be the situation for HEI employees (teachers, administrative staff) and what are the working students 'engagement related to future teaching methodology (online, hybrid, offline), as there is still little literature related to motivation, exhaustion and occupational health related to online delivery and assessment, except McCann \& Holt (2009) (Walker et al., 2020, p.7).

This continuous research will bring more data related to HEI leadership that must have disperse attention to multiple stakeholders, as the new set of competencies and skills may determine the HEI survival itself. They should be able to redesign long-term strategies based on adaptive business models, to be aware of partners' evolution in order to find suitable solution for their clients, the students, be sensitive to staff health but also development needs when we emerge from pandemic (Greenberg \& Hibbert, 2020) and updated resources accordingly, as well as their motivation as satisfaction is fallen prior to lockdown (Times Higher Education, 2020b).

HEI leadership should be able to send out the message for job security, as "according to Probst et al. (2007) job insecurity is positively related to productivity, but negatively related to creativity, which may actually be a great source of concern, especially as creativity may be a crucial element for the quality of online delivery" (Walker et al., 2020, p.25), so the core of the existing and future business model.

\section{References}

Adair, J. (1979). Action-Centred Leadership. Aldershot, United Kingdom, Gower.

Altbach (2011). The Past, Present, and Future of the Research University. In Altbach, P.G. \& Salmi, J. (Eds.). The Road to Academic Excellence, 11-32, Washington DC, The World Bank.

Amey, M. J. (2006). Leadership in Higher Education, Change, The Magazine of Higher Learning, $38,55-58$.

Astin, A.W., \& Astin, H.S. (2000). Leadership Reconsidered: Engaging Higher Education in Social Change. Battle Creek, MI, W.K. Kellogg Foundation. 
Bass, B.M. (1997). Does the Transactional-Transformational Leadership Paradigm Transcend Organizational and National boundaries?, American Psychologist, 52, 130-139, http://dx.doi.org/10.1037/0003-066X.52.2.130.

Bass, B.M., \& Avolio, B.J. (1993). Transformational Leadership and Organizational Culture, Public Administration Quarterly, 17, 112-121.

Bălan, Mădălina, Marin, Silvia, Mitan, Andreea, Pînzaru, Florina, Vătămănescu, Elena-Mădălina and Zbuchea, Alexandra. "Leaders in focus: generational differences from a personalitycentric perspective", Management \& Marketing. Challenges for the Knowledge Society, 14(4), 2019, 372-385, https://doi.org/10.2478/mmcks-2019-0026.

Bennis, W. (1999). The Leadership Advantage, Leader to Leader, 12, 18-23, http://dx.doi.org/ 10.1002/lt1.40619991205.

Bennis, W. (2009). On Becoming a Leader (Revised Edition), New York, Addison-Wesley Publishing.

Black, S.A. (2015). Qualities of Effective Leadership in Higher Education, Open Journal of Leadership, 4, 54-66, http://dx.doi.org/10.4236/oj1.2015.42006n.

Black, S. A., Groombridge, J.J., \& Jones, C.G. (2011). Leadership and Conservation Effectiveness: Finding a Better Way to Lead, Conservation Letters, 4, 329-339, http://dx.doi.org/ 10.1111/j.1755-263X.2011.00184.X.

Blumenstyk, G. (2014). American Higher Education in Crisis? What Everyone Needs to Know, Oxford University Press, Retrieved from https://www.amazon.com/American-HigherEducation-Crisis-Everyone/dp/0199374082.

Brammer, S., Clark, T. (2020). COVID-19 and Management Education: Reflections on Challenges, Opportunities, and Potential Futures, British Journal of Management, 31(3), 453-456.

Brandenburg, U. (2020). Internationalisation in higher education for society - IHES in the times of corona, Social Education, 8(1), 11-24, https://doi.org/10.7441/soced.2020.08.01.01, ISSN 1805-8825.

Bratianu, C., Prelipcean, G., and Bejinaru, R. (2020). "Exploring the latent variables which support SMEs to become learning organizations", Management \& Marketing. Challenges for the Knowledge Society, 15(2), 154-171, DOI: 10.2478/mmcks-2020-0010.

Brookings (2020). School closures, government responses, and learning inequality around the world during COVID-19. Retrieved from https://www.brookings.edu/research/schoolclosures-government-responses-and-learning-inequality-around-the-world-during-covid$19 /$.

Clegg, S., \& McAuley, J. (2005). Conceptualising Middle Management in Higher Education: A Multifaceted Discourse, Journal of Higher Education Policy and Management, 27, 9-34, http://dx.doi.org/10.1080/13600800500045786.

Defazio, D., Lockett, A., \& Wright, D. M. (2009). Funding Incentives, Collaborative Dynamics and Scientific Productivity: Evidence from the EU Framework Program, Research Policy, 38, 293-305.

Deming, W. E. (1982). Out of the Crisis. Cambridge, MA, MIT Center for Advanced Engineering Study.

Fernandez, A.A., Shaw, G.P. (2020). Academic Leadership in a Time of Crisis: The Coronavirus and COVID-19: Academic leadership in a time of crisis, Journal of Leadership Studies, 14(9), DOI: 10.1002/j1s.21684.

Fink, S. (2002). Crisis Management: Planning for the Inevitable. Lincoln, NE, iUniverse Inc. 
Gamage, K.A.A., Roshan Pradeep, R.A.A., Najdanovic-Visak, V., Gunawardhana, N. (2020). Academic Standards and Quality Assurance: The Impact of COVID-19 on University Degree Programs, Sustainability, 12, 10032; doi:10.3390/su122310032.

Gigliotti, R.A. (2020). Crisis Leadership in Higher Education: Theory and Practice. New Brunswick, NJ, Rutgers University Press.

Gmelch, W. H., Roberts, D., Ward, K., and Hirsch, S. (2017). A retrospective view of department chairs: lessons learned. Depar. Chair 28, 1-4, doi: 10.1002/dch.30140.

Goffee, R., \& Jones, G. (2009). Clever: Leading Your Smartest, Most Creative People. Boston, MA, Harvard Business Press.

Goleman, D. (1997). Emotional Intelligence, New York, Bantam.

Gumus, S., Bellibas, M. S., Esen, M., \& Gumus, E. (2018). A systematic review of studies on leadership models in educational research from 1980 to 2014, Educational Management Administration \& Leadership, 46(1), 25-48.

Harris, A. (2020). COVID-19 - school leadership in crisis?, Journal of Professional Capital and Community, 5(3/4), 321-326.

Heifetz, R. A., \& Laurie, D. L. (1997). The Work of Leadership, Harvard Business Review, 75, 124-134.

Hersey, P., \& Blanchard, K. H. (1969). Life Cycle Theory of Leadership, Training Development, 23, 26-34.

Hersey, P., Blanchard, K.H., Natemeyer, W.E. (1979). Situational Leadership, Perception, and the Impact of Power, Group Organ. Stud., 1979, 4, 418-428. [CrossRef]

Herzberg, F. (1976). One More Time: How Do You Motivate Employees?. Harvard Business

IAU (2020a). Regional/National Perspectives on the Impact of COVID-19 on Higher Education. Retrieved from: https://www.iau-aiu.net/IMG/pdf/iau_covid-19_regional_perspectives_ on_the_impact_of_covid-19_on_he_july_2020_.pdf.

IAU (2020b). The impact of COVID-19 on higher education around the world. https://www.iauaiu.net/IMG/pdf/iau_covid19_and_he_survey_report_final_may_2020.pdf.

IAUP (2020). Leadership responses to COVID-19. A global survey of college and University Leadership. Retrieved from https://www.iaup.org/wp-content/uploads/2020/11/Report_ IAUP-Santander-Leadership-Responses-to-COVID-19.pdf.

Kaplan, A. M., \& Haenlein, M. (2016). Higher education and the digital revolution: About MOOCs, SPOCs, social media, and the Cookie Monster, Business horizons, 59(4), 441-450.

Kennedy, C. (1994). Managing with the Gurus, London, Random House.

Kruse, S. D. (2020). Department chair leadership: exploring the role's demands and tensions. Educat. Manage, Administrat. Leadership, Retrieved from doi: 10.1177/1741143220953 601.

Lynch, B.M.; McCormack, B.; McCance,. (2011). T. Development of a model of situational leadership in residential care for older people, J. Nurs. Manag, 19, 1058-1069.

Lynch, M. (2016). 4 Major Types of Educational Leadership. The Edvocate. Retrieved from https://www.theedadvocate.org/4-major-types-of-educational-leadership/.

New York, NY: Oxford University Press.

O'Malley, B. (2020). University leaders say 'We were not ready for COVID-19'. Retrieved from https://www.universityworldnews.com/post.php?story=20201114101555634.

Pucciarelli, F., \& Kaplan, A. (2016). Competition and strategy in higher education: Managing complexity and uncertainty, Business Horizons, 59(3), 311-320. 
Sa, M.J, Serpa, S. (2020). The COVID-19 Pandemic as an Opportunity to Foster the Sustainable Development of Teaching in Higher Education, Sustainability, 12, 8525; doi:10.3390/ su12208525.

Saroyan, A., Getahun, D., Gebre, E. (2011). Understanding Leadership: Perception of Department chairs and Faculty. Retrieved from: https://www.researchgate.net/publication/269947011.

Schloss, P. J., and Cragg, K. M. (2013). Organization and Administration in Higher Education. New York, NY, Routledge.

Singh, A., Haynes, M. (2020). The challenges of COVID-19 in nursing education: The time for faculty leadership training is now, Nurse Educ Pract., 47, 102831.

Stephens, K. K., Malone, P. C., \& Bailey, C. M. (2005). Communicating with stakeholders during a crisis: Evaluating message strategies, The Journal of Business Communication, 42(4), 390-419.

Tourish, D. (2008). Challenging the Transformational Agenda: Leadership Theory in Transition?, Management Communication Quarterly, 21, 522-528, http://dx.doi.org/10.1177/08933189 07313713.

Tran, H. P. (2019). How authentic leadership promotes individual knowledge sharing: viewing from the lens of COR theory, Management \& Marketing. Challenges for the Knowledge Society, 14(4), 386-401. doi: https://doi.org/10.2478/mmcks-2019-002.

Visser, W., Courtice, P. (2011). Sustainability Leadership: Linking Theory and Practice, Social Science Research Network.

Weick, K. E., Sutcliffe, K. M., and Obstfeld, D. (2005). Organizing and the process of sensemaking, Organizat. Sci., 16, 409-421. doi: 10.1287/orsc.1050.0133.

Yan, Z. (2020). Unprecedented pandemic, unprecedented shift, and unprecedented opportunity, Human Behavior and Emerging Technologies, 2, 110-112. 